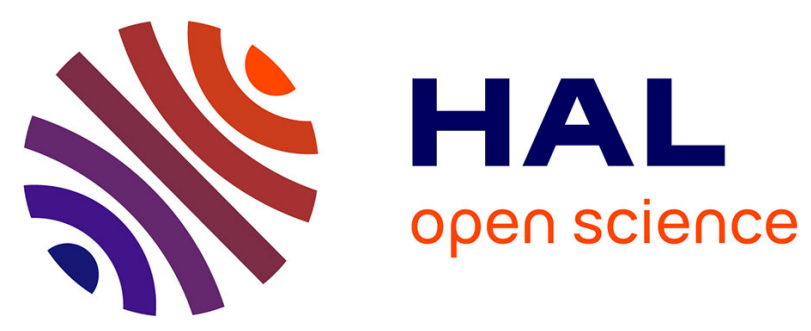

\title{
Total organic carbon evaluation of heterogeneous coaly facies using well logs data, Carboniferous Lorraine Basin
} (France)

\author{
Allouti Salim, Raymond Michels, Alain Izart, Monbo-Mouketo Metzger, \\ Fabrice Malartre, Danièle Bartier, Yves Géraud, Nassif Fady
}

\section{To cite this version:}

Allouti Salim, Raymond Michels, Alain Izart, Monbo-Mouketo Metzger, Fabrice Malartre, et al.. Total organic carbon evaluation of heterogeneous coaly facies using well logs data, Carboniferous Lorraine Basin (France). 30th International Meeting on Organic Geochemistry - IMOG 2021, Sep 2021, Online, France. hal-03429713

\section{HAL Id: hal-03429713 https://hal.science/hal-03429713}

Submitted on 15 Nov 2021

HAL is a multi-disciplinary open access archive for the deposit and dissemination of scientific research documents, whether they are published or not. The documents may come from teaching and research institutions in France or abroad, or from public or private research centers.
L'archive ouverte pluridisciplinaire HAL, est destinée au dépôt et à la diffusion de documents scientifiques de niveau recherche, publiés ou non, émanant des établissements d'enseignement et de recherche français ou étrangers, des laboratoires publics ou privés. 
TOTAL ORGANIC CARBON EVALUATION OF HETEROGENEOUS COALY FACIES USING WELL LOGS DATA, CARBONIFEROUS LORRAINE BASIN (FRANCE).

\author{
Allouti S. ${ }^{1}$, Michels R. ${ }^{1}$, Izart A. ${ }^{1}$, Mombo-Mouketo M., Malartre F. ${ }^{1}$, Bartier D. ${ }^{1}$, \\ Géraud Y. ${ }^{1}$, Nassif F. ${ }^{2}$ \\ ${ }^{1}$ Université de Lorraine, CNRS, GeoRessources lab, UMR7359, 54500 Vandœuvre-lès- \\ Nancy, France \\ ${ }^{2}$ La Française de l’Energie, 57380 Pontpierre, France
}

The last coal mine in Lorraine (France) closed down in 2004 due to the loss of French mines competitiveness. The amount of coal still buried in the Lorraine underground represent an important resource of coal bed methane. This type of resource is considered both as an unconventional reservoir and an alternative energy for France which contains a low carbon footprint. Currently a new exploration campaign is being carried out in the French part of Carboniferous basin and new data are available.

The Saar-Lorraine Carboniferous Basin is about $300 \mathrm{~km}$ long and $20 \mathrm{~km}$ wide. The main part of the sedimentary filling consists of $5 \mathrm{~km}$ of fluvio-lacustrine deposits of the Westphalian in which the coal series develop. Westphalian strata are overlain by fluvial-dominated continental series of Stephanian in which coal is almost absent and finally a Permo-triassic cover of about $500 \mathrm{~m}$ thickness.

There is an important interest in the Westphalian and Stephanian formations in the SaarLorraine basin as a potentially prospective coal bed methane. Coal, shale and coaly shale are the most prominent source rocks in the Lorraine basin. One key parameter to evaluate the potential gas generation is the total organic carbon content (TOC). There are well-known methods to estimate TOC in the laboratory such as carbon analyzers or Rock-Eval pyrolysis. However, sampling of the core or drill cuttings is very costly and the TOC estimated in this case is discontinuous along sedimentary profiles. To overcome this limitation, several methods are derived from well logs. In Saar-Lorraine basin well logs for analysis are readily available and some drilling cores avilable to provide samples to be analyzed as to calibrate the results from logging data.

Recent publications describe methods of TOC determination by well-logs applied to marine clay deposits, yet application to continental coal bearing strata is much more scarce. A major problem to over-come is linked to the complexity of the sedimentary successions. The fluvial facies are dominant and characterized by fining upward depositional sequences which evolve from conglomerate to sandstone, silt, clay and sometimes coal. Thicknesses and extension in space of facies may vary significantly, due to local controlling factors. These were characterized by the study of facies sedimentology, depositional environment interpretation and genetic depositional sequence analysis using core data and well-log analysis.

Two different TOC estimation techniques from well logs data, $\Delta \log \mathrm{R}$ (Passey et al., 1990) and Carbolog (Bessereau et al., 1991) were used within Techlog Schlumberger software with the aim to provide a best estimation for our continental fluvio-lacustrine coal bearing strata as well and coal bed methane reservoirs. These two methods rely on the response of well logs to organic matter using an overlay of sonic wave and resistivity logs. Furthermore, contrary to Carbolog, the application of $\Delta \log \mathrm{R}$ requires the determination of level of organic maturity (LOM) for each formation. LOM was determined using the correlation table proposed Hood at al. (1975) for vitrinite reflectance either measured by organic petrography or estimated from 
Rock-Eval Tmax values. This study is applied on three wells on the eastern part of the basin (Folschviller, Diebling and Johannsweiler) and three others on the western side (Saulcy, Lorettes and Chaumont ).

Results show that there is high agreement between TOC estimated values using well logs and core measurements for sandstones. However, both $\Delta \log \mathrm{R}$ and Carbolog methods tend to underestimate TOC when compared to the available TOC measurements for coal, coaly shale and shale. It appears that the very large range of TOC values (from 0 to 100\%) is a challenge in the application of the methods, especially when kerogen is very concentrated in coal seams.

Objectives of this presentation will be to explain why TOC is underestimated for shales and coal seams, how to correct the calculated values and how this impacts the source-rock volumes estimates. It will also be presented how this information combined to facies analysis, depositional environment and genetic interpretation contributes to assess source-rock distribution in these very heterogenous sedimentary series.

This work is part of the Regalor project: Coalbed Methane Resources in Lorraine for a low carbon energy. https://regalor.univ-lorraine.fr/en/regalor-2/

\section{References}

Bessereau, G., Carpentier B., and Huc A. Y.. (1991). Wireline Logging and Source RocksEstimation Of Organic Carbon Content By The Carbolog Method." The Log Analyst MayJune, 279-297.

Hood, A., Gutjahr C. C. M., and Heacock R. L.. (1975). Organic metamorphism and the generation of petroleum." AAPG bulletin 59.6 986-996.

Passey, Q. R., Creaney S, Kulla J. B., Moretti F. J. and Stroud J. D. (1990). A practical model for organic richness from porosity and resistivity logs. AAPG bulletin 74, 1777-1794. 